WIENER SLAVISTISCHES JAHRBUCH, Band 56/2010, 99-108

(C) 2010 by Österreichische Akademie der Wissenschaften, Wien

ROMAN MNICH

\title{
Іван Франко і єврейство ${ }^{1}$
}

1. Для франкознавства заявлена у заголовку цієї розвідки проблема є важливою з огляду на декілька причин, серед яких я би визначив три як пріорітетні.

По-перше, йдеться про вельми важливі для історії української культури і літератури стосунки Івана Франка з визначними діячами єврейської культури або євреями, що долучились до творення культури польської чи австрійської (німецькомовної). Цей аспект може і мусить досліджуватись у ракурсі історичному, бо без історичного підходу буде неможливим аналіз ставлення Івана Франка до єврейства; а це ставлення було зумовлене як характером та постаттю українського письменника, так і ситуацією українців, поляків та євреїв у Галичині під владою Габсбурзькій монархії на кінець 19 - початок 20 століття.

По-друге, важливим для франкознавства $є$ вивчення та інтерпретація так званого єврейського дискурсу у творчості Івана Франка, тобто всього обсягу матеріалу (художнього, публіцистичного, документального, епістолярного, сатиричного, фольклорного), що стосується єврейства. Усі дослідники життя та творчості письменника погоджуються з тим, що Іван Франко $\epsilon$ постаттю винятковою і дуже контроверсійною, коли йдеться про осмислення єврейської проблематики: у його художніх творах ми зустрічаємо як наскрізь позитивні, та і негативні образи євреїв.

По-третє, з єврейством, нарешті, пов'язане у Івана Франка осмислення цілого ряду біблійних образів та мотивів, котрі через історичні типології проектувались письменником на сучасну йому українську дійсність. Центральним твором у цьому випадку є поема Мойсей, де історична єврейська проблематика (народ у неволі, що потребує визволителя, пророка-поводиря) прямо пов’язується з історичними завданнями народу українського через звернення автора у

1 Текст є частиною проекту „Іван Франко і єврейство“ („Ivan Franko und das Judentum“, Projekt M1025-G03, Lise-Meitner-Programm, Fonds zur Förderung der wissenschaftlichen Forschung, Wien). 
першому рядку твору: „Народе мі й, замучений, розбитий“ (курсив мій Р. М.). Окрім Мойсея у подібному контексті треба інтерпретувати принаймні ще і поему Смерть Каӥна та переспіви псалмів з циклу На старі теми.

2. Важливим та найчастіше дискутованим $є$ питання про антисемітизм Івана Франка. Підсумковим та найкращим на сьогоднішній день дослідженням цієї проблеми є розділ „Франко та його євреі““ у монографії Ярослава Грицака Пророк у своій вітчизні. Франко та його спільнота (1856-1886); цей дослідник опублікував також польськомовну версію свого текстуㄹ․ Загальні висновки Я. Грицака такі:

„Дослідникам єврейського питання неважко означити погляди молодого Франка: вони є виявом т.зв. ,прогресивного антисемітизму“, що ставить собі за мету використати єврейське питання для поширення революційних настроїв та дій. На відміну від „консервативного“ антисемітизму, прогресивний принципово виступає проти шовінізму і расизму, а також проти використання антисемітизму для захисту і легітимації старого режиму. Хоча така класифікація передбачає чіткий поділ на „прогресивний“"та „реакційний“ підвиди антисемітизму, насправді у політичному житті Східної Європи XIX-XX століть тяжко здистилювати чисте й чітке позиціонування публічних постатей себе саме так, а не інакше. Але за будь-яких обставин конечними умовами, відмова від яких виводила поза межі „прогресивного“ антисемітизму, були підтримка емансипації євреїв і принципове протистояння організованому „реакційному“" антисемітизмові“ ${ }^{\circ 3}$.

Я. Грицак з докладністю історика аналізує і пише про такі важливі проблеми, як: єврейське питання в автономній Галичині, Франків досвід спілкування з євреями молодих літ, Франко і єврейське питання у 1881-1883 роках, дискусія про єврейське питання у часописі Przeglad Społeczny, і насамкінець про Франків випадок у порівняльному аспекті з постатями Віктора Адлєра і Елізи Ожешкової.

Треба однак зазначити, що пропоноване дослідником окреслення Івана Франка як „прогресивного антисеміта“ не є таким однозначним і простим 3 огляду на саму справу прогресивного антисемітизму у Галичині кінця 19 - початку 20 століття ${ }^{4}$. Позиція та інтерпретація Я. Грицака $\epsilon$ серединною поміж

2 Див.: Ярослав Грицак, Пророк у свойй вітчизні. Франко та його спільнота (18561886), Київ 2006, с. 335-363; Jarosław Hrycak, Między filosemityzmem i antysemityzmem - Iwan Franko i kwestia żydowska, w: Swiat NIEpożegnany. A World We Bade No Farewell. Żydzi na dawnych ziemiach wschodnich Rzeczypospolitej w XVIII-XX wieku. Jews in the Eastern Territories of the Polish Republic from 18th to 20th century. Ed. by Krzysztof Jasiewicz, Warszawa - Londyn 2005, s. 451-480.

3 Ярослав Грицак, Пророк у своїй вітчизні. Франко та його спільнота (1856-1886), Київ 2006, с. 359.

4 Пор. хоча б спеціальну розвідку на цю тему Бодуена де Куртене: J. Baudouin de Courtenay, W sprawie ,antysemityzmu postepowego“ (Odbitka z „Krytyki“), Kraków 1911. 
статтями про Івана Франка як своєрідного філосеміта 5 та Івана Франка як явного антисеміта ${ }^{6}$. Щоправда, книжка Я. Грицака доводить події із життя письменника лише до 1886 року, але висновки дослідника є узагальненими і скоріше накреслюють перспективу ставлення I. Франка до єврейської проблематики взагалі, ніж замикають це ставлення у певний період життя письменника.

3. Напевно, наші сьогоднішні уявлення про антисемітизм трохи відмінні від тих філосемітських та антисемітських реалій, у яких жили галичани за часів Франца Йосифа I (передусім через страшний досвід голокосту у 20 столітті). Інакше важко зрозуміти, яким чином „прогресивний антисеміт“ Іван Франко спілкувався і співпрацював з такими видатними євреями в історії європейської культури, як Вільгельм Фельдман, Натан Бірнбаум, Віктор Адлер, Герман Бар, Альфред Носсіг, нарешті Мартін Бубер. Кожен із цих видатних діячів по-своєму сприймав Івана Франка, але поза усяким сумнівом ніхто із названих тут людей не вбачав у постаті українського письменника „прогресивного антисеміта““. Ось, наприклад, що згадує Михайло Мочульський про зустрічі Івана Франка із Вільгельмом Фельдманом:

Ще скажу кілька слів про Вільгельма Фельдмана. Фельдман - була цікава людина. Він походив з бідної сімї маломістечкових хасидів, на 17-му році життя скінчив народню школу і власною працею та енергією добився того, що зайняв визначне місце в польському культурному життю: був журналістом, літературним критиком і автором книги „Piśmiennictwo polskie“. У 1891 році він сидів на лаві обвалованих за належність до соціалістичної партії (в акті обжалування „socjalistyczno-dekadentystycznеј“) і мав марку радикала, симпатика робітничого руху та прихильника українців. Від 1902 року я листувався з Фельдманом і дописував часом до його журналу „Krytyka“. Користаючи з мого знайомства, він у січні 1905 року написав до мене, що їде до Росії, не $з$ агітацією, тільки з інформаційною метою, що може буде по дорозі у

5 Про „образи євреїв у наскрізь позитивному світлі“, та про те, що „єврейська тема була для Франка органічною“, а „українство і єврейство він розглядав як майже співмірні супідрядні поля в колоніальному бутті і всією силою серця та інтелекту прагнув бачити їх не ворогуючими“ див.: Зенон Гузар, Сврейська тема у творчості Івана Франка, в: Підготовчі матеріали популярної енциклопедії „Українське єврейство“, випуск 4, Київ 1999, с. 90. Напевно і найгрунтовнішу щодо текстів самого I. Франка розвідку Петра Кудрявцева про єврейську справу у творчості письменника теж можна охарактеризувати як „проєврейську“. „Виразно соціалістичний світогляд“ І. Франка, про який пише П. Кудрявцев вже у першому абзаці своєї розвідки, був, очевидно і тим методологічним стержнем, на якому вчений будував свій текст. Див.: Проф. П. Кудрявцев, Єврейство, євреї та єврейська справа в творах Івана Франка, „Збірник праць єврейської історично-археографічної комісії“. Том II. У Києві 1929, с. 1-81. У цьому ж контексті пор. також: М. Гнатюк, Іван Франко і деякі проблеми життя єврейської людності в Галичині, „Українське літературознавство“", випуск 58, Львів 1993, с. 78-86.

${ }^{6}$ Від статті Іван Франко $і$ жидівське питання, надрукованій у газеті „Краківські вісті““ (число 112 (850) від 28 травня 1943 року) під криптонімом „К.к.““ (авторство належить Анатолю Курдидику (1905-2001), див. про це у монографії Я. Грицака, с. 526) до останніх публікацій Василя Яременка у книзі: Пантелеймон Куліш, Микола Костомаров, Іван Франко, Жидотрєпаніє ..., Київ 2005. 
Києві, і просив мене, щоб я здобув для нього які листи від Франка або Павлика до кого з визначних українців. В кілька днів після того листу він уже був у Львові, відвідав мене, і сказав мені, що він хоче бачитися з Франком, але боїться, чи він схоче 3 ним говорити, бо що недавно написав якусь неприємну статтю проти нього. Я розказав про все те Франкові, але він усміхнувся і сказав: „Нехай прийде до „Віденської каварні““ вполудень“. Я прийшов з Фельдманом в означеному часі до каварні. Фельдман почав просити Франка вибачення, але Франко про ніщо не хотів слухати, побалакав з ним приязно і дав йому декілька інформацій та лист, мабуть, до ак. Сергія Єфремова“"

Таких, в основі своїй позитивних спогадів про стосунки І. Франка з євреями до наших днів дійшло досить багато, як і спогад самого письменника про його єврейських знайомих ${ }^{8}$. І. Франко навіть протиставляє євреїв християнам (полякам і русинам) щодо ставлення до себе. Так, у передмові до вибраних віршів Вольфа Еренкранца Збаразького письменник, згадуючи про своє знайомство 3 єврейськими вченими, зокрема з Ізидором Бернфельдом (1855-1926), зауважив, що у Дрогобичі він „товаришував 3 жидівськими студентами та пролетаріями“, бо „християни, русини й поляки переважно цуралися“ його9.

4. Надзвичайно цікавими для франкознавства $є$ такі постаті в історії єврейської культури і державності, як Теодор Герцль і Мартін Бубер. Що стосується зафіксованої у спогадах Василя Щурата зустрічі Івана Франка з Теодором Герцлем у Відні 1893 року, то очевидно все ж таки, що це була вигадка В. Щурата - зустрічі як такої не було ${ }^{10}$. Натомість зустрічі Івана Франка з Мартіном Бубером цілком ймовірні у Львові, в 1903 році. Листи М. Бубера до І. Франка збереглися і були надруковані у німецькому виданні текстів I. Франка за редакцією Е. Вінтера і П. Кірхнера (зі сторони української це видання готували О. Білецький і I. Басс, що мали безпосередній доступ до архіву письменника у Києві та доступ до різноманітних матеріалів у Львові). На жаль, не збереглися

${ }^{7}$ Михайло Мочульський, Іван Франко. Студї̈ та спогади, Львів 1938, с. 81-82. Зауважу, що у примітці до цих слів М. Мочульський пише про те, що „в книзі Stronnictwa i programy polityczne $w$ Galicji показав Фельдман українцям свої ріжки і 3 приводу цієї книги ми перестали листуватись, а в часи війни він показав себе україножером і в Берліні агітував проти українців“"(с. 81).

8 Оригінальний текст цих спогадів вперше опубліковано в німецькому виданні творів письменника (Ivan Franko, Meine jüdischen Bekannten, in: Ivan Franko, Beiträge zur Geschichte und Kultur der Ukraine. Hrsg. von E. Winter und P. Kirchner, Berlin 1963, S. 50-58). Загалом у тексті євреї зображені позитивно, щоправда остання фраза спогадів залишається двозначною і загадковою („Bald sollte aber ein unerwarteter Schicksalsschlag mich in eine ganz andere Lebenssphäre schleudern und mir Gelegenheit vollauf verschaffen, das menschliche - auch das jüdische - Leben von einer ganz anderen Seite kennenzulernen").

9 Цит. за текстом у 36 томі Зібрання творів Івана Франка у 50-ти томах (Київ 1982, c. 20).

10 Див. про це: Roman Mnich, Ivan Franko und Theodor Herzl: Über eine nicht stattgefundene Begegnung in Wien im Winter 1893, Wiener Slavistisches Jahrbuch 55 (2009), S. 235-243. 
листи Івана Франка до М. Бубера, принаймні у архіві М. Бубера в Срусалимі їх немає $^{11}$. Вперше серйозну увагу на листування I. Франка з М. Бубером звернув Леонід Рудницький, але дослідник ніяк не коментував самої суті справи, про яку йшлося у листах. Нагадаю, що на запрошення М. Бубера I. Франко планував співпрацю з журналом Der Jude (цей журнал заснував і видавав М. Бубер) i для журналу письменник написав текст „Meine jüdischen Bekannten“. Однак текст I. Франка не був надрукований М. Бубером. Але найцікавішим у цій істоpiї є лист Мартіна Бубера до I. Франка з жовтня 1903 року, у якому М. Бубер просить про зустріч від свого імені і від імені Матіяса Ахера (Натана Бірнбаума). Нагадаю, що Натан Бірнбаум був автором самого терміну сіонізм, засновником єврейської студентської організації у Відні Кадіма та, зрештою, дописувачем українського часопису „Ruthenische Revue“, на шпальтах якого порівнював історичну долю євреїв та українців у парадигмі модерністичних націоналізмів $^{12}$. М. Бубер у згаданому листі підкреслює, що зустріч повинна стосуватись питань, цікавих для І. Франка. Така можлива зустріч Мартіна Бубера, Натана Бірнбаума та Івана Франка може бути темою окремої розвідки.

Зауважу, що Оксана Забужко у своїй книзі Філософія украӥнської ідеї та європейський контекст. Франківський період невідомо чому подає помилкову інформацію про „Франкові статті, надруковані в Der Jude ${ }^{\text {‘13 }}$. Тексти I. Франка, як я уже згадав, ніколи не друкувались у цьому журналі. Ризиковано писати і про „опосередкування сіонізму“ по відношенню до української ідеї, оскільки I. Франко критично ставився до самої ідеї Т. Герцля, як не можна також припускати 3 огляду на вище названі причини і можливих рекомендацій Т. Герцля щодо I. Франка. Ці ж помилки фігурують у другому, виправленому виданні книжки О. Забужко ${ }^{14}$. Сучасні дослідники пишуть про те, що спогади Івана Франка про євреїв не могли бути надруковані у журналі М. Бубера, бо не відповідали інтенції журналу єврейської модерни ${ }^{15}$. Можливо таке пояснення не цілком відповідає дійсності, бо три тексти про євреїв на Україні журнал

11 Принагідно висловлюю вдячність професорові Володимиру Хазану (Срусалимський університет) за відповідні пошуки в архіві М. Бубера (ім'я Івана Франка не значиться взагалі серед матеріалів архіву).

12 Порівняймо зокрема такі слова Н. Бірнбаума: „Die Ruthenen aber als ein Volk, das gleich den Juden zu bescheidenem Nationalismus erzogen ist, das mit gesundem Instinkt vor dem Assimilierungszwange zurückschreckt, werden zufrieden sein dürfen, wenn die nationale Bewegung der Juden in dem hier gezeichneten Sinne verläuft" (Mathias Acher: Die jüdisch-nationale Bewegung, „Ruthenische Revue“ 1905, Nr. 15, S. 376).

13 Див.: Оксана Забужко, Філософія украӥнської ідеї та європейський контекст. Франківський період, Київ 1993, с. 81.

14 Див.: Оксана Забужко, Філософія украйнської ідеї та європейський контекст. Франківський період, Київ 2006, с. 97.

15 Див.: Verena Dohrn, Reise nach Galizien. Grenzlandschaften des alten Europa, Frankfurt am Main 1991, S. 76. 
„Der Jude“ (1916-1924) все ж таки надрукував ${ }^{16}$, не кажучи вже про численні тексти 3 історії життя польських євреїв (а Галичина на цей час була частиною Польщі), в тому числі блискучий філософський етюд знаменитого філософа неокантіанця Германа Когена Польський єврей ${ }^{17}$. Згадаємо нарешті, що у кінці 1916 року редакція часопису оголосила про публікацію в наступному році розвідки „Українці і євреї“ („Ukrainer und Juden“), котру мав підготувати відомий пізніше дослідник історії і культури галицьких євреїв Берль Локер (Berl Locker, 1887-1972), але цей текст не був надрукований.

5. Наступною важливою темою франкознавства, пов'язаною з єврейським дискурсом, є сприйняття Іваном Франком творчості таких авторів, як: Макс Нордау, Георг Брандес, Віктор Адлєр, редактори часопису „Die Zeit“ Гайнріх Каннер та Ізідор Зінгер тощо. У випадку з багатьма із них ми можемо говорити і про конкретні зустрічі та розмови I. Франка з цими людьми, чи то під час поїздок українського письменника до Відня, чи, наприклад, під час поїздки Г. Брандеса до Львова у 1898 році. Розмови та листування Івана Франка із названими тут представниками єврейської інтелігенції до сьогодні не досліджені. Зрозуміло, що не завжди тематика контактів українського автора із цими постатями стосувалась єврейства, частіше власне не стосувалась, особливо коли йдеться про таких асимільованих євреїв, як, скажімо В. Адлєр чи його жінка Емма Адлєр ${ }^{18}$. Для нас важливішою постає інша проблема: як сприймав I. Франко творчість цих єврейських авторів, що читав з їх творів і як прочитане інтерпретував. Адже навіть на основі відомих текстів Івана Франка, таких, скажімо, як Інтернаціоналізм і націоналізм у сучасних літературах, ми можемо стверджувати, що І. Франко студіював твори Г. Брандеса і М. Нордау. А два томи монографії М. Нордау Entartung (1892-1893), яку автор присвятив знаменитому психіатрові і криміналістові Чезаре Ломброзо і у якій піддав критиці парадигму європейського модернізму, I. Франко читав досить таки уважно. Але у всіх названих тут випадках тема антисемітизму не порушувалась і ставлення I. Франка до цих авторів і їх творів ніяк не було обумовлене чи пов'язане із єврейською проблематикою.

6. Безпосередньо справи єврейства Іван Франко торкнеться у дискусії із такими єврейськими авторами, як Карпель Ліппе (Carpel Lippe, 1830-1915), Леопольд Каро (Leopold Caro, 1864-1939), Альфред Hосcir (Alfred Nossig, 18631943), Є. Хасін (псевдонім Хаїма Житловського - Chaim Zhitlowski, 1865-

16 Див.: 1) Abraham Korkis, Die wirtschaftliche Lage der Juden in Galizien, „Der Jude“, 1917-1918, S. 464-471, 532-538, 608-615; 2) Mark Wischnitzer, Volksbildung in der Ukraine, „Der Jude“, 1920-1921, S. 741-743; 3) Benzion Rubstein, Die ökonomische Lage der Juden in der Ukraine und ihre Perspektiven, „Der Jude“, 1921-1922, S. 524-544.

17 Herman Cohen, Der polnische Jude, „Der Jude“, 1916, S. 149-156.

18 Про це докладніше у згаданій монографії Ярослава Грицака. 
1943), частково Вільгельм Фельдман (Wilhelm Feldman, 1868-1919). Головним чином дискусія I. Франка на тему єврейства представлена двома його розвідками, початково друкованими польською мовою. Це стаття 1887 року Semityzm $i$ antysemityzm $w$ Galicji $^{19}$, надрукована у часописі „Przegląd Społeczny“ та цикл статей 1893 року $\dot{Z} y d z i$ o kwestji żydowskiej, друкованих у додатку до газети „Kurjer Lwowski“, додаток називався „Tydzień“. До цієї ж тематики примикає рецензія Івана Франка на книжку Теодора Герцля Єврейська держава ${ }^{20}$, оскільки письменник у цій рецензії теж висловлюється на теми єврейства та сіонізму. Загальне історичне тло цих дискусій Івана Франка теж не досліджене, як не досліджена співвіднесеність (наукова і ідеологічна) текстів українського автора з цитованими ним єврейськими авторами.

Для франкознавства вельми важливим у цьому випадку є інтертекстуальний аналіз проблеми, особливо з огляду на те, що I. Франко пізніше сам перекладав деякі із своїх текстів, і зроблені письменником українські переклади, якими сьогодні користуються українські дослідники, не завжди співпадають із старшим за часом польським оригіналом. А вже аналіз текстів тих єврейських авторів, з якими дискутує I. Франко свідчить про величезну складність самої проблеми, складність наукову та ідеологічну ${ }^{21}$, бо І. Франко виступає одночасно як представник русинів (українців) Галичини, як громадянин Австроугорської монархії і як представник своєї партії (а тут мусимо брати до уваги „партійну“ еволюцію письменника).

7. Напевно, окремо у контексті європейської проблематики у житті та творчості Івана Франка треба інтерпретувати поему Мойсей, оцей „вершок гебраїзму“, як їі назвав П. Кудрявцев у згаданій нижче розвідці. Саме у П. Кудрявцева ми маємо спробу досить докладного (як на той час та можливості дослідника) аналізу усього спектру літературного єврейського дискурсу Івана Франка: від фольклору і апокрифів до індивідуальної творчості. Дослідник, правда, не торкається глибше персональних взаємин I. Франка з євреями, але натомість підходить до оцінки постаті Івана Франка ще без „універсальної канонізації“, зазначаючи, зокрема, що „Франко не був істориком, і даремно було б шукати в

19 „Przegląd Społeczny“, 1887, tom 3, zeszyt 5, s. 431-444.

20 Dr. Iw. Franko: Państwo żydowskie, „Tydzień. Dodatek literacki do Kurjera Lwowskiego". We Lwowie 9 marca 1896, s. 73-74.

21 Висловлюю принагідно вдячність професору Джону Гледу (John Glad) з Вашингтонського університету за допомогу та копію із Бібліотеки Конгресу США розвідки Карпеля Ліппе Symptome der Antisemitischen Geisteskrankheit (Jassy 1887), а також професору Єрусалимського університету Володимиру Хазану за копію розвідки Е. Хасина Еврей к евреям (Лондон 1892). 
нього вичерпливих історичних дослідів у якій-небудь справі“, „Франко спирається не на власне вивчення єврейсько-рабинських джерел“22 тощо.

У випадку з поемою Мойсей ми не маємо ще і до сьогодні критичного видання цього твору I. Франка. Таке видання мусить враховувати як джерела повстання твору (від Біблії і канонічного тексту Житія Мойсея, авторства Григорія Ніського до Ю. Словацького, К. Устияновича тощо), так і його рецепцію. Наскільки у поемі присутній власне єврейський дискурс - ця проблема ще не проаналізована на належному рівні, але дослідники, особливо у пострадянський час, забувають про абсолютно критичну і негативну рецепцію Мойсея I. Франка з боку релігійних представників української інтелігенції. Так Гавриїл Костельник писав про I. Франка:

„Слово в слово він усе прийняв, що давала йому вже оклепана „вільнодумна“ струя. Цілою душею пристав він до сеї „школи“. I через ціле своє життя він був тільки ії пропагатором та популяризатором, то переспівуючи іiї загальну ідеологію, то стосуючи дотепи сеї ідеології до поодиноких конкретних випадків... Але ж через ціле життя остався він атеїстом, а в дійсності невільником плитонької собі „філософії освічення“" (Aufklärungs-Philosophie, яка спізнилась у нас о цілих 130-120 літ) 3 домішкою пізнішого німецького вбого-плитонького матеріалізму. I витрачував він свої сили на складання многих, ріжних, довгих і коротких віршів „освічення“, що глузують 3 позитивної віри в Бога, яких ціла краса полягає в дотепі, питомому всім гумористичним часописам. Він навіть науковою прозою береться воювати проти християнської релігії (його критика св. книжок Нов. Завіта), - як колиб сі річи через світових „вільнодумців“-фахівців не були десять разів ліпше опрацьовані в тому самому дусі. Так Франко, ступивши раз на фатальну дорогу саме на тому полі, яке для поета - так сказати би - „матірнє“, сам зіпхнувся до ролі популяризатора та пропагатора. Жаль, що так сталось - але сього вже не відкликати“љ23.

У цьому контексті поема Мойсей представляє не стільки релігійне осмислення історії нації (української через єврейську), скільки „фанатичний раціоналізм та убогий матеріалізм“24, і навіть більше - у інтерпретації Г. Костельника єврейська тематика поеми I. Франка спровадилась до проповіді „большевизму“ $^{625}$, вже знаного, бо книжка Г. Костельника виходила у 1923 році. Такий „конфлікт інтерпретацій“, звичайно, вимагає грунтовнішого дослідження на

${ }^{22}$ Проф. П. Кудрявцев: Сврейство, євреї та єврейська справа в творах Івана Франка, „Збірник праць єврейської історично-археографічної комісії“. Том II. У Києві 1929, c. 38,45 .

23 Др. Гавриїл Костельник, Ломання душ, Львів 1923, с. 53-55. Ця критика не була одинокою, бо ще за життя Івана Франка він оголошувався представником „псевдокультурного світу“, пропагандистом „модерного ідолопоклонства“, „матеріалістом“, що ніколи не узнає християнського неба, „що дітей своїх не хотів хрестити“ $i$ був ,явним ворогом всього, що відноситься до віри в Бога“, словом „свідомий ворог Христа“, що отруює душі молоді (див.: Ник. Садовський: Християнське становище в справі 40-літнього ювілею Ів. Франка. Жовква 1913, passim).

24 Др. Гавриїл Костельник, Ломання душ, Львів 1923, с. 77.

25 Др. Гавриїл Костельник, ор. cit., с. 86. 
ширшому історичному тлі, але варто зауважити, що вже у 1886 році (тобто майже два десятиліття перед написанням поеми) Іван Франко у своїй статті про Мойсея Мендельсона, посилаючись на I. Канта, писав про те, що „закон Мойсея зовсім не накладає пута на духа і совість“²6.

8. Ще один важливий аспект заявленої теми складають розвідки та дослідження Івана Франка, присвячені єврейському фольклорові та єврейським елементам в українському фольклорі. Тут слід назвати публікації 1894-1895 років iз журналу „Житє і слово“, тексти із редагованого С. Ф. Краусом часопису „Am Ur-Quell“, а також тексти 3 двох томів українського еротичного фольклоpy $^{27}$, підготовлених і виданих Володимиром Гнатюком у 1909 і 1912 роках. Напевно до цього ж типу творів примикає цикл поетичних оповідей про Швинделеса Пархенбліта (Швинделеса Пархенбліта вандрівка з села Дерихлопи до Америки $і$ назад, а також інші антиєврейські публікації з сатиричного часопису „Нове зеркало“). Як правило, в українському фольклорі та у названих публікаціях Івана Франка ми маємо справу з переважно негативними постатями євреїв, осмислення та інтерпретація яких потребує окремих досліджень.

9. Над сьогоднішнім українським літературознавством, на жаль, тяжіє ще комплекс „української класики як канону та іконостасу“, у зв’язку з чим біографії українських письменників у працях науковців постають як ,житія святих“, а не як життєписи реальних людей з їхніми суперечками, з їхньою правдою і неправдою (а часто і просто брехнею), з їхніми моральними, а деколи і неморальними поступками.

У сучасному українському франкознавстві почасти бракує справжнього історичного підходу до вивчення життя та творчості Івана Франка. Може тому найкраща біографічна та історична монографія про Івана Франка - книжка Ярослава Грицака Пророк у своїй вітчизні - так неоднозначно була сприйнята декотрими науковцями. Страх перед власною історією та національною історичною правдою прикривається патріотичними лозунгами, у тіні яких аж ніяк не може досліджуватись така складна проблема, як українсько-єврейські культурні та історичні відносини. У цій площині вже чимало зроблено, але ще залишається велике неоране поле для досліджень: від єврейського дискурсу в давній українській літературі (згадаймо тільки наскрізь позитивну постать плачучої Рахилі в українському вертепі) до антисемітизму Свгена Маланюка. Проблема також полягає і у тому, що у дотеперішніх дослідженнях єврейсько-

${ }^{26}$ Иванъ Франко, Мозесъ Мендельзонъ - реформаторъ жидо́́вскій, „Зоря“ 1886, число 7 , c. 115.

27 Див.: Das Geschlechtsleben des ukrainischen Bauernvolkes. Folkloristische Erhebungen aus der Russischen Ukraina. I. Teil. Leipzig 1909; Das Geschlechtsleben des ukrainischen Bauernvolkes in Österreich-Ungarn. Folkloristische Erhebungen von Volodymyr Hnatjuk. II Teil. Leipzig 1912. 
українських взаємин переважали біблійні впливи на українську культуру (котpi, до речі, були переважно не стільки єврейськими, скільки християнськими).

Повертаючись до постаті Івана Франка, зазначу, що для цього письменника характерною $є$ взагалі полярність або інакше кажучи амбівалентність в оцінці та зображеннях історичних фактів, окремих людей, чи суспільних явищ. Це стосується практично всього: від власної сімейної ситуації письменника (такими амбівалентними $є$ висловлювання Івана Франка про Ольгу Хорунжинську) до суджень про Берестейську унію (і взагалі роль християнства в історії Свропи) і про конкретних людей - Михайла Грушевського, Миколи Драгоманова тощо. Це ж саме стосується і єврейського дискурсу у текстах I. Франка.

Ми мусимо пам'ятати про те, що в історії культури - як і в історії людства взагалі - бувають дивні збіги і не до кінця збагненні парадокси. Саме такі парадокси характерні і для життя та творчості Івана Франка: чи то йдеться про історію його одруження, чи його відомий $i$, очевидно, несправедливий випад проти Адама Міцкевича, чи лозунги письменника про те, що він „не любить русинів і Русі“, чи його випади проти М. Павлика, М. Драгоманова, чи його хворобу (до сьогодні не проаналізовану історично та біографічно), чи - нарешті - ставлення Івана Франка до єврейства. Це ставлення може бути досліджене та прокоментоване тільки на широкому історичному тлі подій та біографії письменника, бо усі інтерпретації, що не враховують такого тла, перетворюються у вигадки та надінтерпретації.

A bstract: Ivan Franko and Jewry. The article presents an analysis of Jewish discourse in Ivan Franko's life and writings, in his relation to Jews, Jewish culture and history. The author interprets Jewish influences upon Franko, the images of Jews in his writings as well as Franko's correspondence and discussions with well-known representatives of Jewish culture (Martin Buber, Alfred Nossig, Wilhelm Feldman, Carpel Lippe, Leopold Caro), and stresses the crucial importance of historical context and a historical approach in interpreting certain elements of Franko's Jewish discourse.

K e y w o r d s: Ivan Franko, Galicia, Jewry, Martin Buber, anti-Semitism

Roman Mnich

Akademia Podlaska, Wydział Nauk Humanistycznych

Instytut Filologii Polskiej

ul. G. Orlicz-Dreszera 19/21, paw. A

08-110 Siedlce, Polen

mnichrw@yahoo.de 